\title{
THE EFFECT OF QUENCHING MEDIA VARIATIONS ON MICRO STRUCTURE AND VIOLENCE OF THE S45C STEEL STEEL WELDING RESULTS
}

\author{
Bagus Supriyadi Nur Haq ${ }^{1}$ \\ ${ }^{1}$ Mechanical Engineering Education, Universitas Sebelas Maret Surakarta \\ Email: bagussnh@gmail.com
}

\begin{tabular}{|c|c|}
\hline KEYWORDS & ABSTRACT \\
\hline $\begin{array}{l}\text { SMAW } \\
\text { S45C steel } \\
\text { Quenching } \\
\text { Microstructure } \\
\text { hardness }\end{array}$ & $\begin{array}{l}\text { The purpose of this research is to find out the effect of current on } \\
\text { microstructure and hardness value in S45C steel before (raw material) and } \\
\text { after welding using Shielded Metal Arc Welding (SMAW). This research using } \\
\text { experiment method. The Technique of data analysis using descriptive } \\
\text { comparative research. The instruments that used for testing microstructure } \\
\text { and hardness is Olympus Metallurgical Microscope and Vickers Hardness } \\
\text { Tester. Based on the results of the research conclude that (1) the results of the } \\
\text { microstructure testing showed the improved martensite structure after } \\
\text { welding. In the raw material, martensite structure didn't exist but the result of } \\
\text { SMAW welding methods using quenching media of water, oil, and air that } \\
\text { showed martensite structure was exist. (2) The hardness value of raw material } \\
\text { is } 232 \text { VHN. The specimen with water media had highest average hardness } \\
\text { value that is } 411 \text { VHN, oil media had average hardness value that is } 308 \text { VHN, } \\
\text { air media had lowest average hardness value that is } 263 \text { VHN. This research } \\
\text { showed that the result of SMAW welding using varying quenching media can } \\
\text { changed the microstructure and hardness of S45C steel. }\end{array}$ \\
\hline
\end{tabular}

\section{INTRODUCTION}

The use of metal in every type of equipment used in human life is evidence of the rapid development of science and technology in the metal industry. The use of metals in each machine component and building construction does not have to be all the same, but must be adapted to the nature, strength and use. Metals still need processing, both on the dimensions and the basic properties they have with various methods of processing, in order to obtain conditions that have the desired capabilities and properties in the application. The nature of the material in question is physical properties and mechanical properties. Physical properties include physical conditions, composition and microstructure. While the mechanical properties include tensile strength, elastric modulus, expansion ability, compressive strength, torsion strength, hardness, tenacity, agility and reliability (Hari Amanto and Daryanto, 1999: 22).

There are several types of steel metal that can be selected as construction materials and machine components, one of which is medium carbon steel. Medium carbon steel is widely used as a machine component because it has the advantage that its mechanical properties can be improved through heat treatment, but it has the disadvantage of easily experiencing weld cracks (Erizal, 2011: 1). The SMAW welding is a metal connection process using electric power as a heat source and electrodes as material added. SMAW welding is widely used, because this welding process besides producing a strong connection is also easy to use (Setiawan, 2016: 2).

During welding, the heat source continues and causes differences in temperature distribution in the metal so that uneven expansion and shrinkage occurs. As a result residual stresses and distortions will arise in welded metals (Putra et al., 2008: 1). The welding process affects the thermal cycle in the area around the weld which 
causes complex metallurgical changes, deformations and thermal stresses. Thermal cycle is the process of heating and cooling in the weld area. One way to control the cooling rate is by heat treatment (Rananggono, 2008: 1). One of the heat treatment processes is quenching which can cause changes in the microstructure. As a result of changes in micro structure, the mechanical properties they have will change as well (Erizal, 2011: 1).

\section{RESEARCH METHODS}

The research was conducted at the Surakarta Institute of Welding and Technology Laboratory (INLASTEK) and the Technical Materials Laboratory, Diploma in Mechanical and Industrial Engineering, Faculty of Engineering, Gadjah Mada University, Yogyakarta.This research is using experimental method. This research is a quantitative research, which describes the results of experiments on a number of specimens, then the data analysis technique uses descriptive comparative methods. Data collection in this study is by observation, documentation and direct experiments. The method used in this research is a method that intentionally and systematically conducts a treatment or action of observing a variable.

The independent variable of this study is a variation of quenching media. Variations in quenching media used are: water, oil and air. The dependent variable of this study is the microstructure and hardness of S45C steel specimens. The control variables of this study are (a) S45C steel specimens. (b) SMAW welding method. (c) 130A welding current. (d) welding direction to the right. (e) welding position under the hand. (f) photo machine for micro structure Olympus PME (Metallurgical Microcope with Inverted). (g) Vickers hardness testing machines. The results of the microstructure testing aim to compare the microstructure of the weld area, the HAZ region and the parent area after welding. SMAW uses a variety of quenching water, oil and air media with microstructure of materials without welding (raw material). The results of the hardness test aim to compare the hardness value of the weld area, the HAZ region and the parent area after welding. The SMAW uses a variety of quenching water, oil and air media with the hardness of raw material.

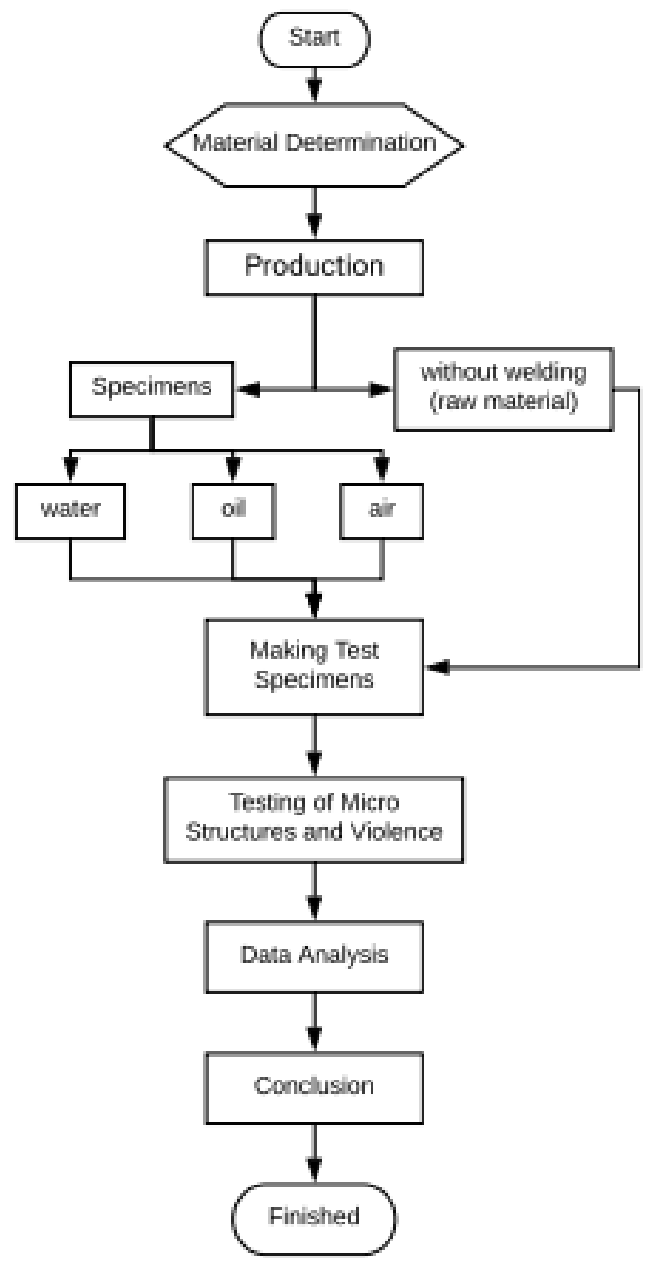

Figure 1. Research Flow Chart 


\section{RESULTS AND DISCUSSION}

Photographs of microstructure were taken in the raw material area, weld area, HAZ area and parent area with 200x magnification.

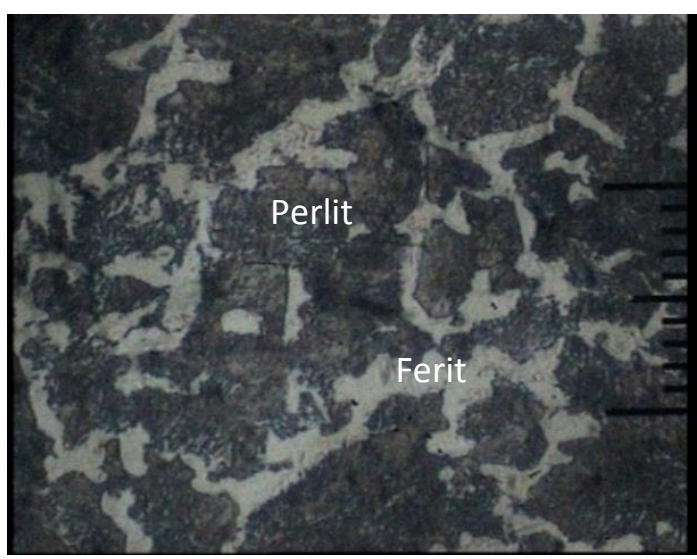

Figure 2. Micro Structure of S45C Steel Raw Material Specimens

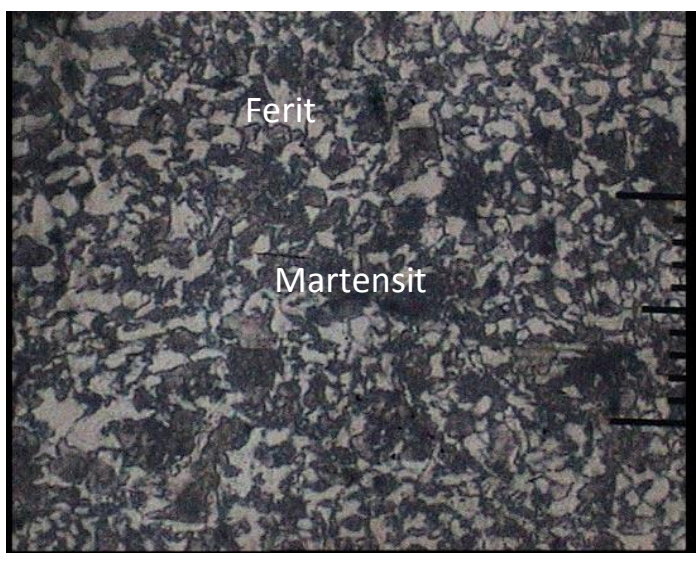

Figure 4. Microstructure of HAZ Region Media Quenching Water

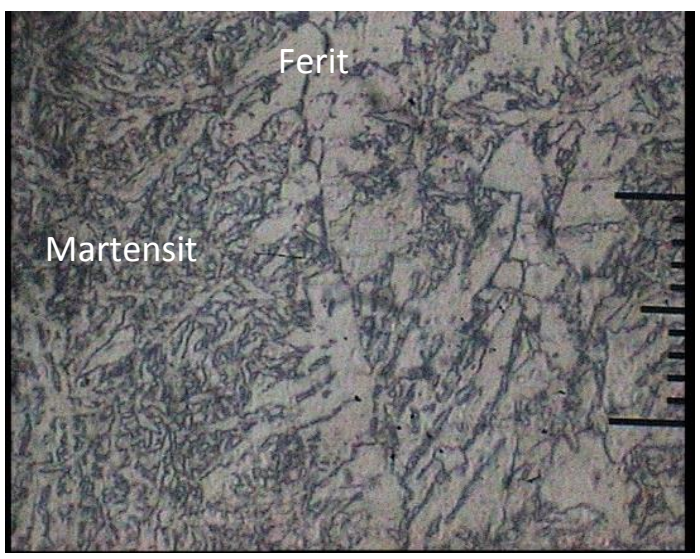

Figure 6. Las Area Micro Structures Media Quenching Oil

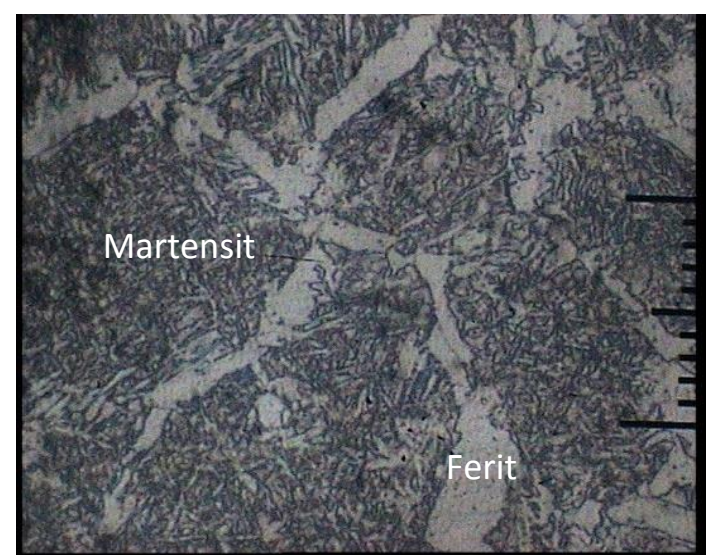

Figure 3. Las Area Micro Structures Media Quenching Water

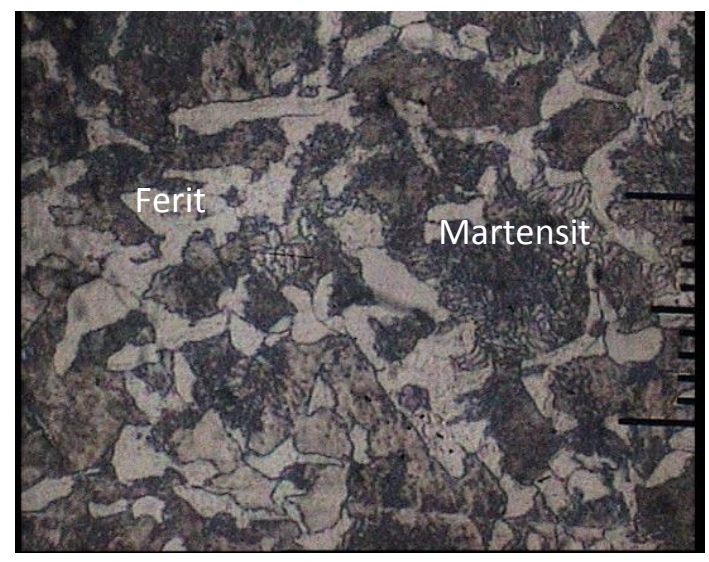

Figure 5. Microstructure of the Main Region of Media Quenching Water

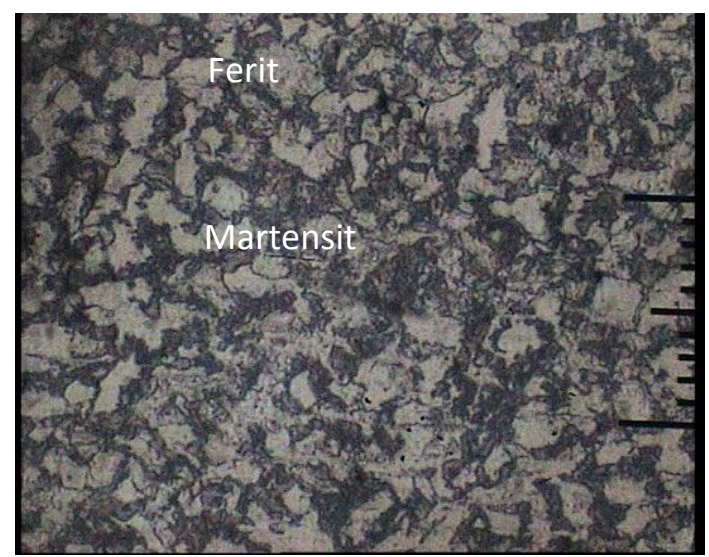

Figure 7. HAZ Regional Microstructure Media Quenching Oil 


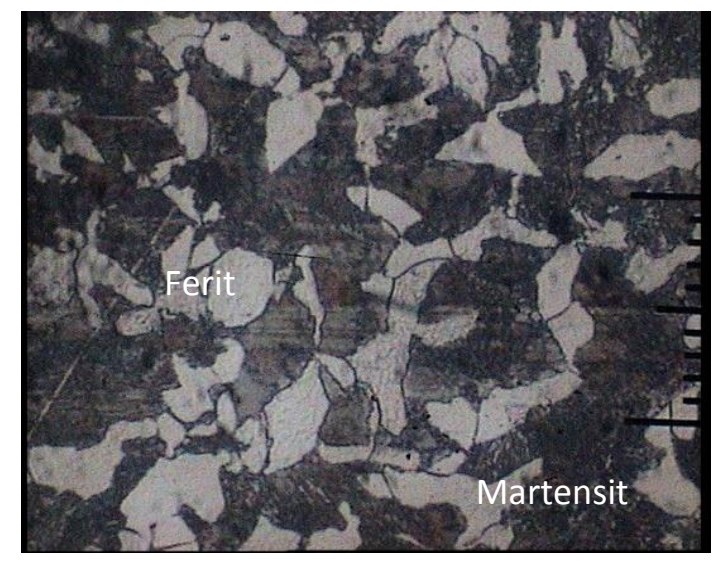

Figure 8. Microstructure of the Main Region of the Media Quenching Oil

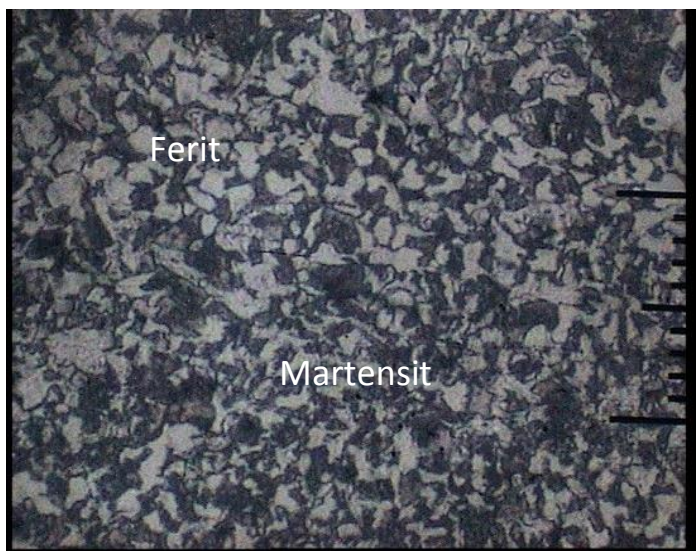

Figure 10. HAZ Regional Microstructure of Media Air Quenching

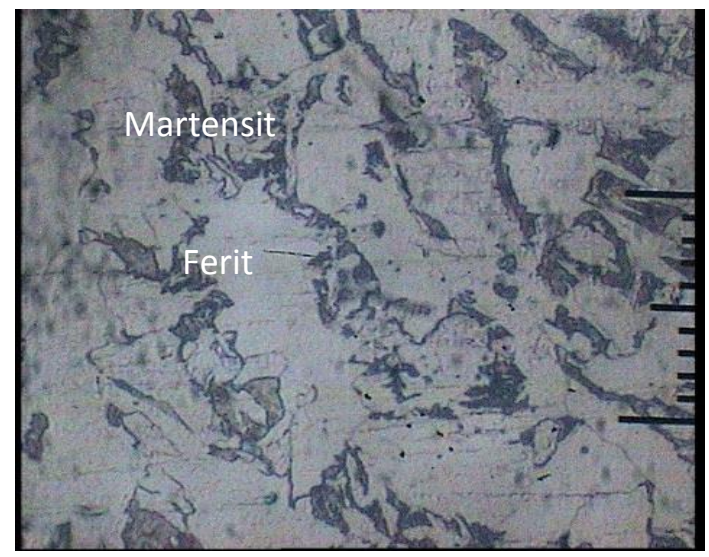

Figure 9. Las Area Micro Structures Air Quenching Media

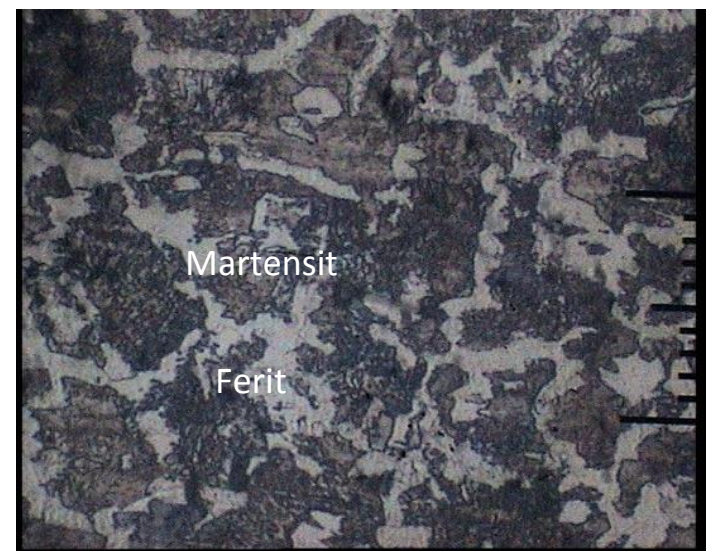

Figure 11. Microstructure of the Main Region of Air Quenching Media

Based on the test results above, it can be concluded that the welding process can affect the formation of micro structures that are different from the basic material (raw material). Quenching media also influences the speed of the formation of martensite in $\mathrm{S} 45 \mathrm{C}$ steel specimens. The most optimal quenching media in hardening metal after welding is water media. The martensitic structure of the water medium is more dominant than other cooling media, so that it can harden the metal better. Whereas quenching media which is the slowest to harden metal after welding is air media. The martensitic structure of the air media tends to be small and uneven. So that the air medium is the longest in metal hardening after welding. Testing of hardness was carried out on S45C steel specimens after welded covering the weld area, HAZ region and parent area.

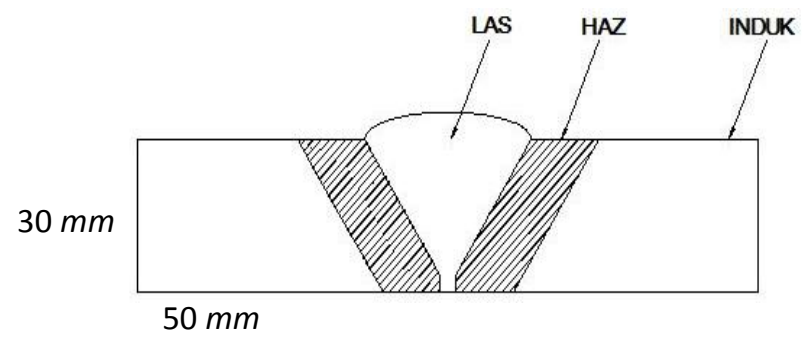

Table 1. S45C Steel Specimen Hardness Test Results (Raw Material)

\begin{tabular}{cccc}
\hline No & Specimens & average of $\mathbf{d}$ & Hardness \\
\hline 1 & & $40 \mu \mathrm{m}$ & \\
2 & $\mathrm{~S} 45 \mathrm{C}$ & $40 \mu \mathrm{m}$ & $232 \mathrm{VHN}$ \\
3 & & $40 \mu \mathrm{m}$ & \\
\hline
\end{tabular}


Table 2. S45C Steel Specimens of Welding Results of Welding Results of SMAW

\begin{tabular}{cccc}
\hline \multirow{2}{*}{ Area } & \multicolumn{3}{c}{ Quenching Media } \\
\cline { 2 - 4 } & Water & Oil & Air \\
\hline \multirow{3}{*}{ Welding } & $412 \mathrm{VHN}$ & $286 \mathrm{VHN}$ & $257 \mathrm{VHN}$ \\
& $412 \mathrm{VHN}$ & $278 \mathrm{VHN}$ & $250 \mathrm{VHN}$ \\
& $441 \mathrm{VHN}$ & $278 \mathrm{VHN}$ & $257 \mathrm{VHN}$ \\
\hline \multirow{4}{*}{$H A Z$} & $570 \mathrm{VHN}$ & $412 \mathrm{VHN}$ & $303 \mathrm{VHN}$ \\
& $593 \mathrm{VHN}$ & $412 \mathrm{VHN}$ & $294 \mathrm{VHN}$ \\
& $549 \mathrm{VHN}$ & $399 \mathrm{VHN}$ & $303 \mathrm{VHN}$ \\
\hline \multirow{3}{*}{ Main } & $244 \mathrm{VHN}$ & $232 \mathrm{VHN}$ & $238 \mathrm{VHN}$ \\
& $244 \mathrm{VHN}$ & $232 \mathrm{VHN}$ & $232 \mathrm{VHN}$ \\
& $232 \mathrm{VHN}$ & $244 \mathrm{VHN}$ & $232 \mathrm{VHN}$ \\
\hline
\end{tabular}

The formula used to determine the value of Vickers specimen hardness is :

$V H N=\frac{\text { beban }}{\text { luas penekanan }}=1,854 \frac{p}{d^{2}}$

Where :

$P=$ load used (kgf)

$\mathrm{d} 1=$ diagonal vertical direction $(\mathrm{mm})$

$\mathrm{d} 2=$ horizontal direction diagonal $(\mathrm{mm})$

$\mathrm{d}=$ average diagonal $(\mathrm{mm})$

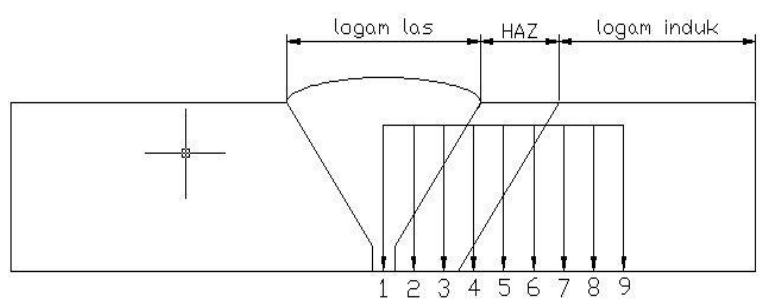

Figure 12. Vickers Hardness Testing Points

VALUE GRAPHICS OF S45C STEEL SPECIMEN HARDNESS

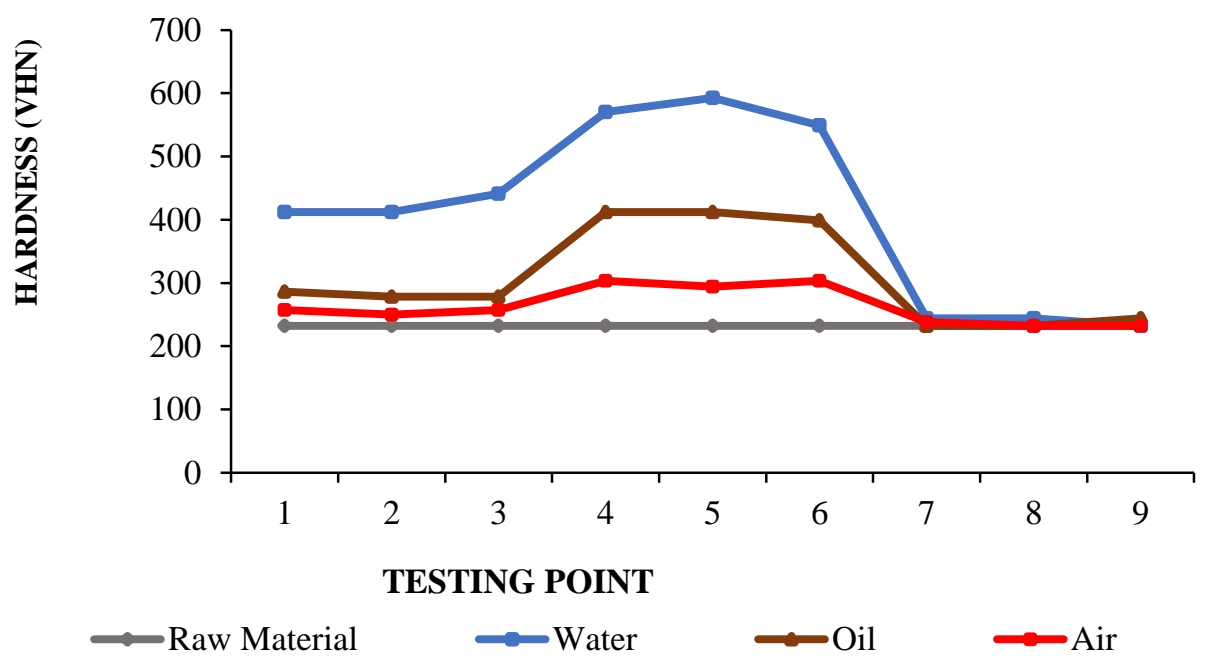

Figure 13. Graph of Value of Hardness of S45C Steel Specimens 


\section{AVERAGE DATA OF S45C STEEL SPECIMEN HARDNESS}

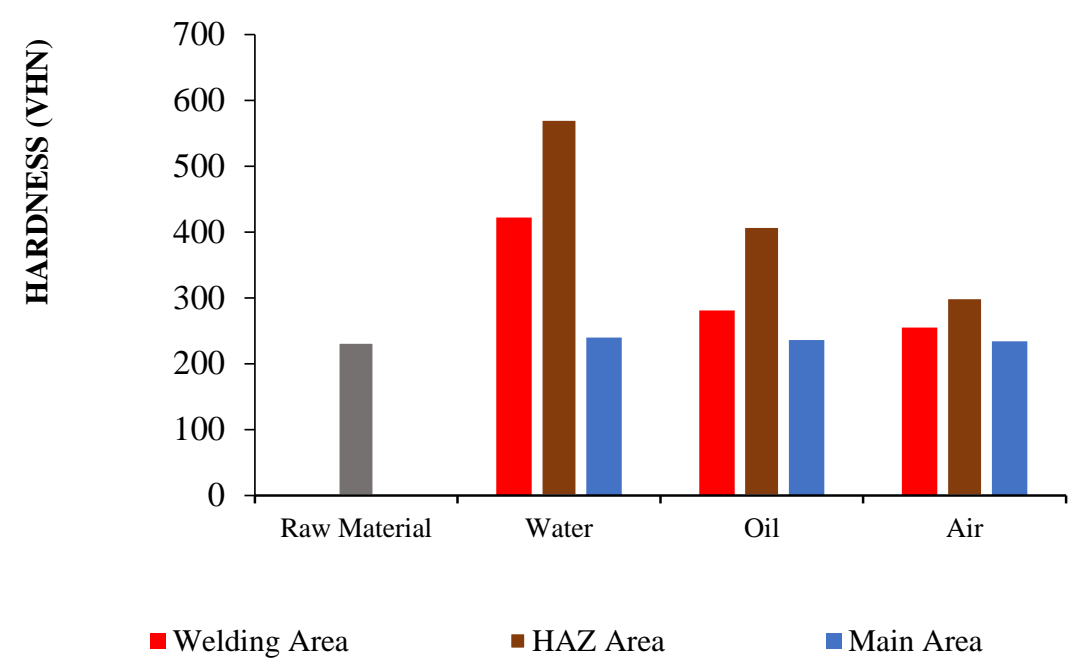

Figure 14. Mean Diagram of the Value of Hardness of S45C Steel Specimens

The hardness value of raw material for $\mathrm{S45C}$ steel specimens at all points is equal to $232 \mathrm{VHN}$. The hardness value in the weld area with water cooling media is $422 \mathrm{VHN}$, up $81.90 \%$ compared to the hardness value of raw material. The hardness value in the HAZ region is $571 \mathrm{VHN}$, up $146.12 \%$ compared to the hardness value of raw material. While the value of hardness in the parent area is $240 \mathrm{VHN}$, up $3.45 \%$ compared to the hardness value of raw material. The average hardness value of this specimen is $411 \mathrm{VHN}$. The hardness value in the welding oil cooling media area is $281 \mathrm{VHN}$, up $21.12 \%$ compared to the hardness value of raw material. The hardness value in the HAZ region is $408 \mathrm{VHN}$, up $75.86 \%$ compared to the hardness value of raw material. While the value of hardness in the parent area is $236 \mathrm{VHN}$, up $1.72 \%$ compared to the hardness value of raw material. The average hardness value of this specimen is $308 \mathrm{VHN}$.

The hardness value in the weld area with air cooling media is $255 \mathrm{VHN}$, up $9.91 \%$ compared to the hardness value of raw material. The hardness value in the HAZ region is $300 \mathrm{VHN}$, up $29.31 \%$ compared to the hardness value of raw material. While the hardness value in the parent area is $234 \mathrm{VHN}$, up $0.86 \%$ compared to the hardness value of raw material. The average hardness value of this specimen is $263 \mathrm{VHN}$. From the results of the data analysis above it can be concluded that water cooling media specimens have the highest average hardness value compared to other cooling media. While air conditioning media specimens have the lowest average hardness value compared to other cooling media. The hardness values in the weld area and HAZ have increased, especially in the HAZ region, this causes the specimens in the HAZ region to be very hard but brittle. While the parent area does not experience an increase in the value of violence because the area is far from the effects of heating and cooling during the welding process.

\section{CONCLUSION}

Quenching media can influence changes in the microstructure of $S 45 \mathrm{C}$ steel specimens. This is evidenced in the results of testing that the microstructure of $\mathrm{S} 45 \mathrm{C}$ steel specimens without welding (raw material) contained only ferrite and perlite structures while the microstructure of S45C steel specimens from SMAW welding and quenching were martensite structures. The faster the cooling rate, the martensitic structure will be formed faster. The more martensitic structure makes the metal harder. Quenching media can influence the value of material violence. Water has the highest density among other media so that the hardness value of $\mathrm{S45C}$ steel specimens uses the highest quenching water media. This is evidenced in the results of testing that specimens with water media have the highest average hardness value of $411 \mathrm{VHN}$, oil media has an average hardness value of $308 \mathrm{VHN}$, air media has the lowest average hardness value of $263 \mathrm{VHN}$. 


\section{REFERENCES}

Amanto, H. \& Daryanto. (1999). Ilmu Bahan. Jakarta: Bumi Aksara.

ASM International. (1991). Heat Treating Volume 4. Untited State of America.

Erizal. (2011). Kajian Eksperimen Pengujian Kekerasan Baja Karbon Medium yang Disambung dengan SMAW dan Quenching dengan Air Laut. Jurnal Teknik Mesin Universitas Prof. DR. Hazairin, SH Bengkulu.

Erizal. (2011). Analisa Struktur Mikro pada Daerah Las dan HAZ Hasil Pengelasan Shielded Metal Arc Welding (SMAW) pada Baja Karbon Medium Dan Quenching Air Laut. Jurnal Teknik Mesin Universitas Prof. DR. Hazairin, SH Bengkulu.

Putra, Y.P., Pintowantoro, S., \& Sadino. (2008). Analisa Tegangan Sisa dan Distorsi pada Pengelasan Fillet T-Joint dengan Metode Elemen Hingga. Jurnal Teknik Material \& Metalurgi Institut Teknologi Surabaya.

Rananggono, D., Mulyadi, Y., \& Winarno, GD. (2008). Studi Kekuatan Mekanik dan Struktur Mikro Hasil Pengelasan SMAW dengan Variasi Preheat dan Postheat Menggunakan Metode Pendinginan Cepat dan Pendinginan Lambat. Jurnal Tugas Akhir Institut Teknologi Surabaya.

Santoso, Joko. (2006). Pengaruh Arus Pengelasan terhadap Kekuatan Tarik dan Ketangguhan Las SMAW dengan Elektroda E7018. Skripsi Universitas Negeri Semarang.

Setiawan, Ferry. (2016). Pengaruh Variasi Sudut Kampuh V dan Kuat Arus dengan Las Shielded Metal Arc Welding (SMAW) pada Baja A36 terhadap Sifat Mekanik. Jurnal IImiah Teknik Mesin Universitas Muhammadiyah Sidoarjo.

Van Vlack. (1985). Elements of Materials Science and Engineering 5th Edition. USA: Addison Wesley Publising Company, Reading, Mass.

Wiryosumarto. (2000). Teknologi Pengelasan Logam. Jakarta: Pradnya Paramita. 